\title{
POTENSI SUMBERDAYA ALAM DAN PENGELOLAANNYA UNTUK MENDUKUNG KEHIDUPAN SOSIAL MASYARAKAT ADAT KAWASAN GUNUNG BATUR BANGLI
}

\author{
IDA BAGUS MADE ASTAWA, DKK.
}

\begin{abstract}
Abstrak
Penelitian ini dilaksanakan di kawasan gunung Batur kabupaten Bangli yang bertujuan untuk mengkaji potensi sumberdaya alam dan pengelolaannya untuk mendukung kehidupan masyarakat adat. Penelitian ini terbagi dalam dua tahapan selama dua tahun. Untuk mencapai tujuan tersebut dirancang penelitian dengan menggunakan rancangan survei pada potensi sumberdaya. Titik sampel pengukuran di lapangan ditentukan secara purposive. Hasil penelitian tahap I menunjukkan bahwa Kawasan Gunung Batur dengan luas $101.24 \mathrm{Km} 2$ adalah daerah asal volkanis berbentuk kaldera dan bermorfologi dominan Dataran Kaki Gunungapi $\left(V_{4}\right)$ yang kemiringan lerengnya umumnya terjal $(>40 \%)$. Kawasan Gunung Batur yang terdiri dari 14 desa dinas dihuni oleh 47,492 orang dengan sebaran lebih besar pada desadesa bermorfologi $V_{4}$ yang topografinya relatif datar. Pendidikan penduduk tergolong rendah dengan dominasi mata pencaharian di sektor pertanian. Pertumbuhan penduduk pertahun tergolong tinggi (2.30\%), namun kepadatan penduduknya tergolong kurang padat. Potensi lahan Kawasan Gunung Batur tergolong jelek (Kelas IV - VIII). Sebagian besar wilayah (83.89\%) kemampuan lahannya bervariasi dari kelas V sampai kelas VIII yang secara luas tersebar pada lembah kaldera dan lereng kaldera. Kemampuan lahan kelas IV, yang bisa ditanami tanaman semusim hanya mencakup sebagian kecil wilayah (16.11\%) yang penyebarannya hanya di sebagian kecil wilayah desa Buahan, Kedisan, dan Songan B. Potensi curah hujan Kawasan Gunung Batur tergolong klasifikasi tinggi (P1), namun kandungan air tanahnya umumnya sangat rendah (Sp1 dengan debit < 0.1 liter/detik) dan dengan kualitas yang sudah mengalami pencemaran. Terkait dengan sumberdaya mineral, Kawasan Gunung Batur memiliki potensi Bahan Galian $C$ berupa pasir dan batu yang tersebar pada sebagian besar lereng dan lembah kaldera (77.64\%). Sedangkan Potensi hutan di Kawasan Gunung Batur berfungsi hutan lindung yang luasnya sebagian besar berupa semak belukar, sedangkan penyebaran hutan dengan pepohonan hanya $5.60 \%$ dari total luas Kawasan Gunung Batur. Potensi pertanian Kawasan Gunung Batur sebagian besar berupa lahan untuk tanaman sayuran dataran tinggi, tanaman palawija, dan tanaman perkebunan. Sedangkan potensi perikanan terdapat di danau Batur yang luasnya $16.5 \mathrm{Km}^{2}$ dengan kedalaman rata-rata $50.8 \mathrm{~m}$, dan memiliki volume air sekitar $816,580,000 \mathrm{~m}^{3}$. Sementara potensi pariwisata yang dapat dikembangkan meliputi pariwisata alam, budaya, dan keilmuan.
\end{abstract}

Kata Kunci : Kawasan Gunung Batur; Kemampuan Lahan; Potensi; Morfologi 


\section{Pendahuluan}

Sumberdaya alam adalah semua unsur tata lingkungan biofisik yang dengan nyata atau potensial dapat memenuhi kebutuhan manusia, atau dengan perkataan lain sumberdaya alam merupakan semua bahan yang ditemukan manusia dalam alam, yang dapat dipakai untuk memenuhi segala kepentingan hidupnya (Katili, 1983). Keberadaan sumberdaya alam dengan segala potensi yang terkandung di dalamnya tidak lepas dengan apa yang disebut ekosistem. Ekosistem dapat diibaratkan sebagai suatu kerajaan, yang di dalamnya terdapat hubungan erat saling ketergantungan satu sama lain, yang merupakan suatu tatanan dari unsur-unsur lingkungan hidup sebagai suatu kesatuan utuh menyeluruh dan saling mempengaruhi dalam bentuk keseimbangan, stabilitas dan produktivitas lingkungan hidup (UULH, 1997). Salah satu bentuk tatanan tersebut dapat dijumpai pada suatu bentanglahan gunungapi.

Indonesia terkenal sebagai negara yang paling banyak (128 buah yang aktif) mempunyai gunungapi di dunia, tiga di antaranya terdapat di Pulau Bali (Gunung Agung, Gunung Batur dan Gunung Batukaru). Pada umumnya masyarakat menganggap bahwa wilayah gunungapi itu memiliki kesuburan tanah yang tinggi, berpenduduk padat, tetapi sering dihadapkan pada resiko bencana alam yang ditimbulkan, seperti erupsi gunungapi, aliran lahar panas maupun lahar dingin, dan longsor lahan. Anggapan masyarakat umum tersebut tidak keliru, namun perlu dukungan data secara kuantitatif. Informasi yang diketahui oleh masyarakat tentang gunungapi kebanyakan adalah tingkat bahayanya, sedangkan data potensi sumberdaya sepenuhnya belum banyak diketahui. Data potensi sumberdaya alam yang terdapat pada ekosistem gunungapi secara utuh dan menyeluruh itu penting diketahui sebagai dasar untuk membuat perencanaan pembangunan yang berkesinambungan. Seberapa besar kemampuan sumberdaya alam yang tersedia pada ekosistem gunungapi dalam mendukung kehidupan masyarakat adat di sekitarnya merupakan suatu permasalahan yang perlu mendapat perhatian dan pemecahan.

Selama ini masyarakat umumnya mengenal gunung Batur dengan panorama alam yang dijadikan sebagai daya tarik wisata alam. Namun demikian, wilayah gunungapi Batur sebagai satu satuan ekosistem belum diketahui secara rinci potensi sumberdaya alam yang tersedia. Kenyataan tersebut menjadikan daya dukung lingkungan di wilayah gunung Baturpun belum diketahui. Untuk mengetahui daya dukung lingkungan perlu didasarkan pada ketersediaan sumberdaya alam dan sumberdaya manusia yang memanfaatkannya. Berkaitan dengan hal tersebut, maka tujuan khusus penelitian ini (tahun ke1) adalah untuk:

(1) mengetahui karakteristik bentanglahan wilayah gunung Batur yang mencakup tipe, agihan dan luasannya;

(2) menganalisis kondisi dan persebaran kependudukan di daerah penelitian, yang mencakup jumlah, pertumbuhan dan kepadatan penduduk pada setiap satuan morfologi gunung batur; dan

(3) mengevaluasi dan menganalisis potensi sumberdaya alam dan pewilayahannya yang terdapat di 
wilayah gunung Batur mencakup sumberdaya alam (lahan, air, tambang dan hutan); dan potensi sosial ekonomi wilayah secara sektoral (pertanian, perkebunan, perikanan dan pariwisata).

Arti penting penelitian ini dari sisi ilmu pengetahuan adalah sebagai satu model penelitian ilmu lingkungan secara terpadu yang mensintesiskan sumberdaya alam dengan sumberdaya manusia. Selain itu penelitian ini juga dimaksudkan sebagai satu model tipe penelitian eksositem gunungapi pada umumnya. Sedangkan ditinjau dari sisi terapannya, adalah tersedianya data potensi sumberdaya alam yang terdapat pada ekosistem gunung Batur baik yang terbaharui maupun takterbaharui. Hal tersebut penting untuk mengatur strategi dalam pengelolaan sumberdaya alam, dan dapat dijadikan model kajian potensi sumberdaya alam pada ekosistem gunungapi serta bahan rujukan untuk pengembangan dan pembangunan berkelanjutan dari ekosistem gunungapi lain di Indonesia.

\section{Metode}

Bahan dalam penelitian ini meliputi, Citra, Peta, Foto Udara, Data Statistik Penduduk, sedangkan alat yang digunakan adalah, Stereoskop cermin, Kaca pembesar, Komputer untuk interpretasi citra, dan Alat survei lapangan (GPS, kompas geologi, palu geologi, pita ukur, EC-meter, soil test kit, Kamera dan Handycam).

Data yang dibutuhkan adalah, data primer dan data sekunder. Data primer meliputi hasil interpretasi peta dan citra (kondisi geologi, hidrologi, geomorfologi, proses dan struktur geomorfologi, klasifikasi curah hujan dan tipe iklim) dan pengukuran lapangan (karakteristik geomorfologi : relief, kemiringan lereng, struktur dan proses; kondisi geologi : jenis batuan dan tipe pelapukan; kondisi hidrologi (kedalaman muka air tanah, tipe mata air, DHL, suhu dan debit aliran); kondisi tanah; tipe penggunaan lahan; dan praktek pengelolaan hutan.

Data sekunder berupa data fisiografi yang dihasilkan penelitian terdahulu, dan data sosial ekonomi yang didasarkan pada data potensi desa dan data Kecamatan Kintamani Dalam Angka tahun 2010, yang meliputi: data kependudukan dan potensi sektoral seperti potensi pertanian, perkebunan, perikanan, peternakan dan pariwisata. Data yang belum lengkap ditelusuri melalui internet. Sampel dan penentuan titik pengukuran di lapangan dengan purposive sampling, yang mempertimbangkan sampel secara merata pada setiap satuan geomorfologi gunung Batur dan mewakili setiap satuan administrasi.

Selanjutnya untuk mengetahui potensi dan persebaran sumberdaya alam di wilayah Batur data dianalisis menggunakan analisis kualitatif dan analisis spasial (khusus untuk mengetahui persebarannya dipermukaan bumi, yaitu dengan memetakan setiap parameter yang diteliti). Parameter yang digunakan adalah, (1) Potensi curah hujan dianalisis berdasarkan besarnya curah hujan rerata tahunan yang jatuh di atas satuan morfologi tertentu, yang terukur pada beberapa stasiun curah hujan yang ada dan diklasifikasikan mengacu pada FAO/CSR (1983, dalam Sutikno.dkk.2007), (2) Potensi mata 
air diklasifikasikan berdasarkan debit terukur dan kualitasnya. Kualitas air dari mata air pada hasil analisis kimia contoh air yang diambil dan didasarkan pada nilai DHL yang terukur. Klasifikasi potensi mata air mengacu pada Satuan Hidrogeologi, Direktorat Geologi Tata Lingkungan (1985), (3) Potensi air tanah dianalisis berdasarkan parameter; kedalaman muka air tanah, permiabilitas aquifer dan kualaitas air tanah. Kualitas air tanah didasarkan pada data hasil analisis kimia air tanah dan $\mathrm{DHL}$, dengan pengklasifikasian mengacu pada Satuan Hidrogeologi, Direktorat Geologi Tata Lingkungan (1985), (4) Potensi sumberdaya lahan dianalisis berdasarkan hasil evaluasi kemampuan lahan dengan parameter kemiringan lereng, erosi tanah, kedalaman efektif, tekstur, permiabilitas, drainase, bahan kasar dipermukaan, salinitas dan ancaman banjir atau genangan. Kemampuan lahan diklasifikasikan menjadi 8 kelas kemampuan lahan dari Kelas I - Kelas VIII berdasarkan yang dikemukakan dalam FAO/ CSR and staff, dan Potensi sumberdaya mineral atau bahan tambang dianalisis berdasarkan jenis dan produksi bahan tambang (terutama golongan $\mathrm{C}$ ) dan persebarannya di gunung Batur. Sementara untuk sumberdaya hutan, potensi dinilai berdasarkan jenis, luas dan persebarannya.

\section{Hasil dan Pembahasan}

1.1. Letak dan Luas Kawasan Gunung Batur/Bentanglahan Wilayah Gunung Batur

Berdasarkan interpretasi dari Citra Landsat 5 Ortho dan Peta Topografi, dapat dikemukakan bahwa secara fisiografis Bentanglahan Wilayah Gunung Batur merupakan bentanglahan wilayah pegunungan (volcanic) berupa "Kaldera"yang dibatasi oleh perbukitan sisa (igir) yang berbentuk melingkar mengelilingi kaldera. Secara astronomis letaknya adalah di antara $115^{\circ} 19^{\prime 2} 28^{\prime \prime}$ BT dan $115^{\circ} 25^{\prime} 34^{\prime \prime}$ BT serta $08^{\circ} 11^{\prime 2} 25^{\prime \prime}$ LS dan $08^{\circ} 17^{\prime} 30^{\prime \prime}$ LS. Sedangkan secara administratif Kawasan Gunung Batur merupakan bagian dari wilayah Kecamatan Kintamani Daerah Tingkat II Kabupaten Bangli.

Terdapat 14 desa yang wilayahnya terletak pada Kawasan Gunung Batur dengan luas $197.37 \mathrm{Km}^{2}$, meliputi desa Kintamani, Kedisan, Buahan, Suter, Abangdinding, Trunyan, Songan A, Songan B, Batur Selatan, Batur Tengah, Batur Utara, Sukawana, Pinggan, dan Blandingan. Namun, hanya $56.44 \%$ (101.24 Km2) bagiannya saja yang masuk sebagai Kawasan Gunung Batur Tabel 1. 
Tabel 1. Luas Desa-Desa Di Kecamatan Kintamani Yang Berada Dalam Kawasan Gunung Batur

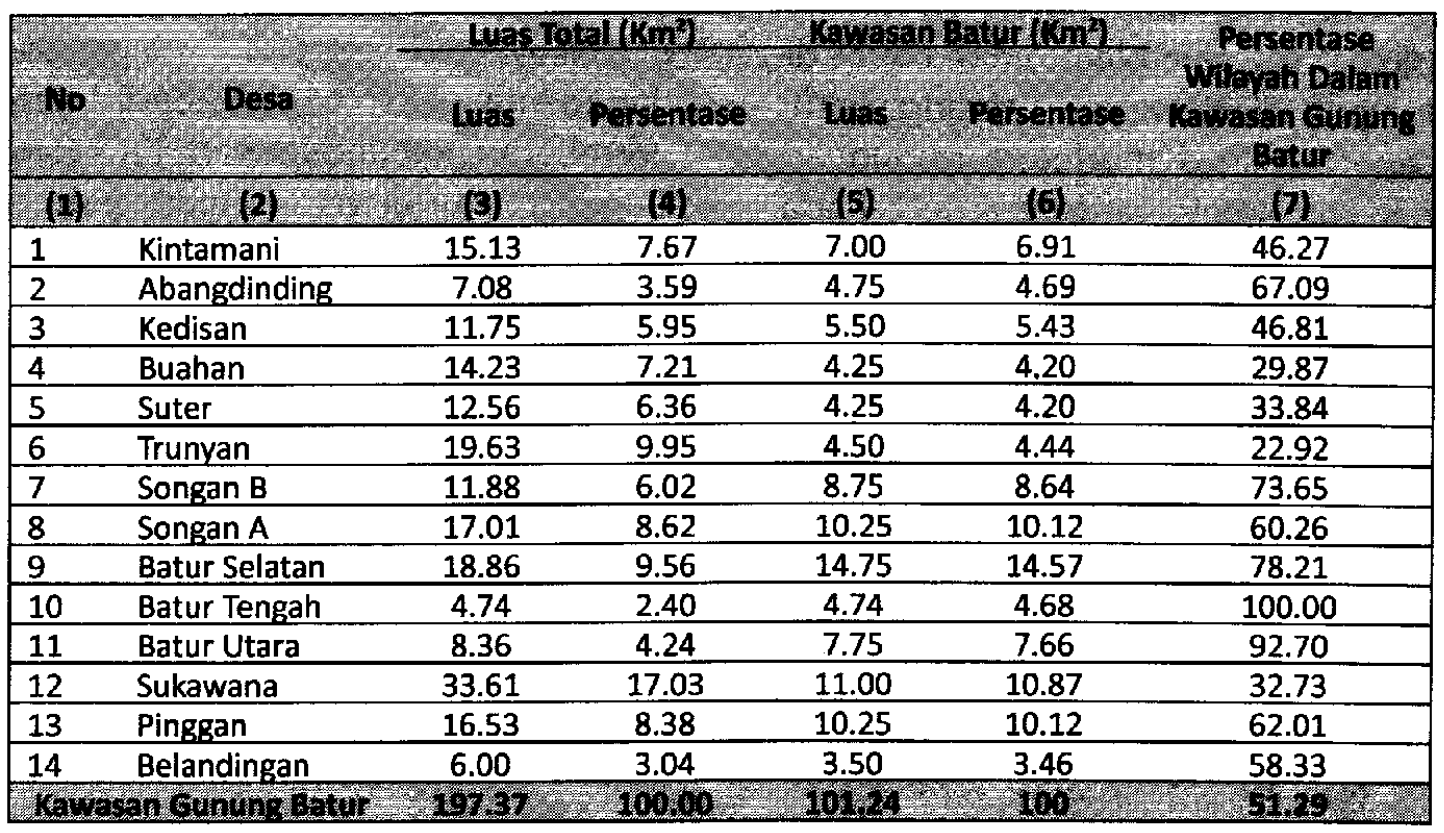

Sumber : Citra Landsat 5 Ortho Skala 1: 50000 Tahun 2002 dan Peta Rupa Bumi Indonesia Tahun 2002 skala 1: 250.000 dan Statistik Kecamatan Kintamani 2009. Diolah Penelit.

1.2. Karakteristik Kawasan Gunung Batur/Bentanglahan Wilayah Gunung Batur

Kawasan Gunung Batur adalah sebuah kaldera dengan luas wilayah $101.24 \mathrm{Km} 2$. yang secara geologis terletak pada komplek gunungapi muda "zone Solo" dengan susunan batuan terdiri dari tiga jenis batuan yaitu, Batuan Gunung Api Batur (Qhvb) dengan aglomerat, tuf, dan lava; Batuan Gunung Api Kelompok Buyan-Beratan dan Batur Purba (Qvbb) dengan breksi dan lava; serta Batuan Gunung Api Kelompok Buyan-Beratan dan Batur Purba (Qpbb) dengan tuf dan endapan lahar. Tiga jenis batuan yang menyusun Kawasan Gunung Batur dan bekerjanya tenaga exogen akan mewarnai tanah yang terbentuk (Regosol Kelabu dan Andosol).

Sebagai sebuah kaldera, Bentanglahan wilayah Gunung Batur memi- liki sebuah danau (Danau Batur) dan gunungapi yang masih aktif (Gunung Batur). Danau Batur tidak memiliki inlet dan outlet, sehingga sumber air danau sangat tergantung air rembesan dan limpasan air hujan yang masuk ke danau. Menyadari akan hal tersebut, maka fungsi orografis lingkungan Kawasan Gunung Batur seperti hutan dan vegetasi lainnya sangat penting untuk dijaga fungsinya sehingga pasokan air ke danau Batur dapat tetap terjaga.

Letusan gunungapi Batur (faktor endogen) dan bekerjanya faktor exogen terutama air dan gravitasi telah menghasilkan morfologi gunungapi Batur yang secara umum dapat dikelompokkan menjadi lima (5), yaitu Kerucut Gunungapi (V1), Lereng Gunungapi (V2), Kaki Gunungapi (V3), Dataran Antara Gunungapi (V4), dan Lembah Danau (F1). Sama halnya de ngan gunungapi Merapi di Yogyakarta 
yang secara morfologi juga dikelompokkan menjadi 5 (Sutikno, 2007:17). Morfologi dataran fluvial gunungapi (fluvial volcanic plain) tidak dapat dijumpai di Kawasan Gunung Batur, seperti halnya morfologi gunungapi pada umumnya yang tidak berkaldera. Kenyataan tersebut menyebabkan sebagian besar Kawasan Gunung Batur wilayahnya memiliki kemiringan lereng $>40 \%$ (terkategori terjal). Daerah dengan kenampakan yang relatif agak datar (berombak) di Kawasan Gunung Batur hanya dimiliki oleh dua desa di pinggiran danau Batur, yaitu desa Songan B dan Batur Tengah dengan luasannya yang sangat sempit.

Kondisi lereng yang seperti dikemukakan menjadikan lahan di Kawasan Gunung Batur memiliki keterbatasan untuk diusahakan. Kondisi tersebut juga ditambah dengan keterbatasan potensi air yang dimiliki Kawasan Gunung Batur. Potensi air hanya terkonsentrasi di danau dan daerah pinggiran danau (air tanah). Dengan demikian sangat dibutuhkan pengelolaan sumberdaya alam di Kawasan Gunung Batur disusun dan dirumuskan berorientasi pada pengelolaan yang berkelanjutan dengan menekankan pada prinsip-prinsip optimalisasi pemanfaatan, berwawasan lingkungan, keadilan, partisipasi rakyat, sebagai upaya meningkatkan kesejahteraan masyarakat sekitar, dengan memperhatikan daya dukung ekosistem untuk kepentingan generasi mendatang.

1.3.Kondisi dan Persebaran Kependudukan Bentanglahan Wilayah Gunung Batur

Data yang berkenaan dengan aspek kependudukan pada dasarnya dapat digunakan untuk melakukan refleksi terhadap pembangunan yang telah terlaksana dan prediksi untuk merencanakan prioritas pengembangan wilayahnya kedepan. Hasil penelitian menunjukkan bahwa kondisi dan persebaran kependudukan Kawasan Gunung Batur di masing-masing desa dengan satuan morfologinya dapat dilihat pada Tabel 2.

Tabel 2 di atas teridentifikasi bahwa penduduk di Kawasan Gunung Batur berjumlah 47492 jiwa, dan tersebar paling banyak di desa Songan B yang bermorfologi lereng gunungapi $\left(V_{2}\right)$, kaki gunungapi $\left(V_{3}\right)$, dan dataran kaki gunungapi $\left(\mathrm{V}_{4}\right)$. Sedangkan yang paling sedikit dihuni oleh penduduk adalah desa Belandingan dengan morfologi dataran kaki gunungapi $\left(V_{4}\right)$ dan lembah danau $\left(F_{1}\right)$. Dari Tabel 2 juga nampak ada kecendrungan satuan morfologi wilayah ada kaitannya dengan besaran sebaran penduduk. Dasa-desa yang disusun oleh satuan morfologi oleh dataran kaki gunung api berkecenderungan proporsi yang lebih besar dibandingkan dengan desa-desa yang disusun oleh satuan morfologi yang lainnya, kecuali desa Blandingan yang secara lokasi terkategori daerah "feri-feri". Adanya permukaan bumi yang relatif datar menyebabkan pengembangan wilayah menjadi lebih mudah sehingga penduduk lebih memilih daerah-daerah dengan relief yang relatif datar untuk tempat tinggal.

$\mathrm{Di}$ samping itu, Tabel 2 memperlihatkan bahwa terdapat variasi kepadatan agraris di Kawasan Gunung Batur. Desa yang kepadatan penduduknya lebih besar dari 100 terdapat hanya di desa Kintamani. Berarti sumberdaya petani di desa Kintamani kepemilikan lahannya 
Tabel 2.

Kondisi dan Persebaran Kependudukan di Bentanglahan Wilayah Gunung Batur Tahun 2010

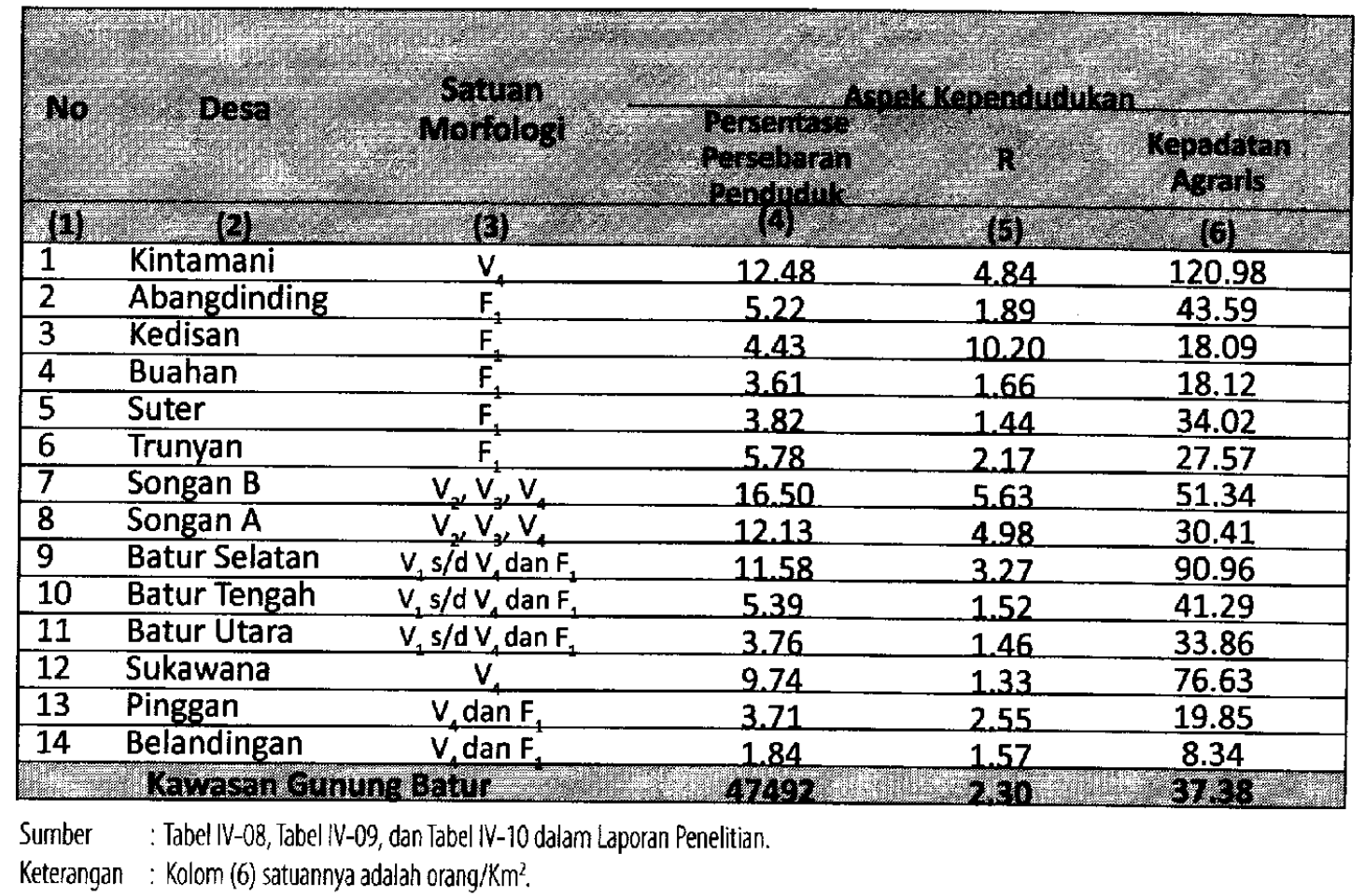

lebih sempit dibandingkan dengan di desa-desa lainnya. Sedangkan desa Blandingan, kepadatan penduduknya adalah yang terendah. Berkenaan dengan pertumbuhan penduduk, secara umum berada di atas pertumbuhan penduduk provinsi Bali yang hanya $1.18 \%$ per tahun. Kenyataan tersebut ke depan akan menjadi beban bagi pembangunan desanya, karena penduduk usia muda akan bertambah banyak sedangkan lahan sulit untuk dikembangkan.

1.4. Evaluasi dan Analisis Potensi Sumberdaya alam dan Pewilayahan Sumberdaya Alam Bentanglahan Wilayah Gunung Batur a. Potensi Sumberdaya Lahan dan Pewilayahannya

Potensi sumberdaya lahan dapat dianalisis berdasarkan kelas kemampuan lahan dan bentuk penggunaan lahan. Berdasarkan kelas kemampuan lahan dan bentuk penggunaan lahan, sumberdaya lahan di Kawasan Gunung Batur dapat dilihat dalam Peta 1

Peta 1 menunjukkan bahwa kemampuan lahan Kawasan Gunung Batur secara umum terdiri dari lima kelas, yaitu dari kelas IV sampai kelas VIII. Berarti kemampuan lahan untuk kelas I sampai kelas III tidak dapat dijumpai di Kawasan Gunung Batur. Semakin tinggi kelasnya semakin jelek kemampuan lahan yang bersangkutan. Untuk jelasnya perhatikan Tabel 3 berikut ini. 


\section{Peta 1}

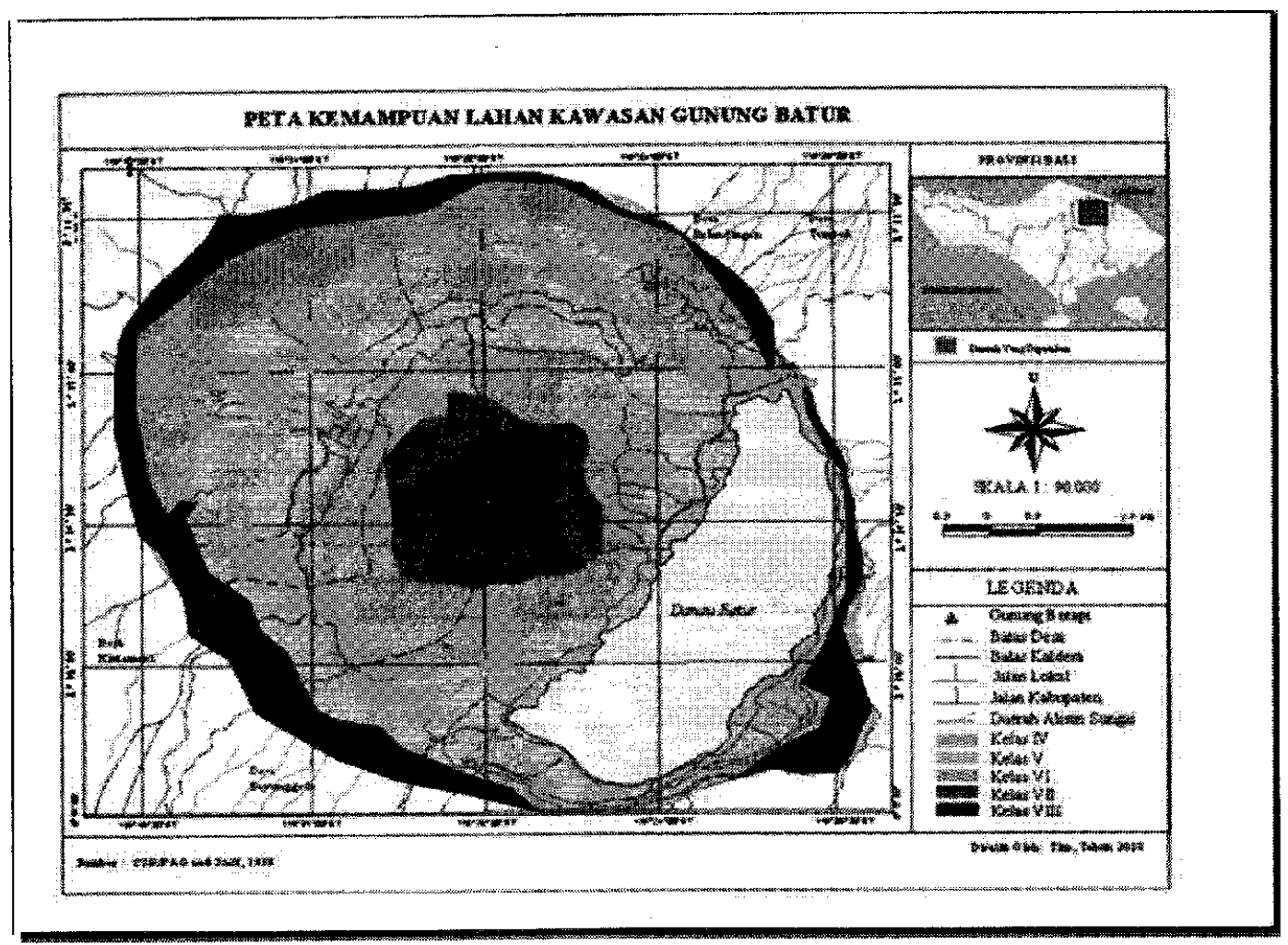

Tabel 3.

\section{Kemampuan Lahan, Kriteria dan Persebarannya di Kawasan Gunung Batur}

\begin{tabular}{|c|c|c|c|}
\hline 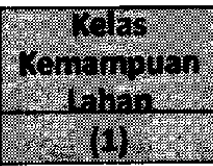 & 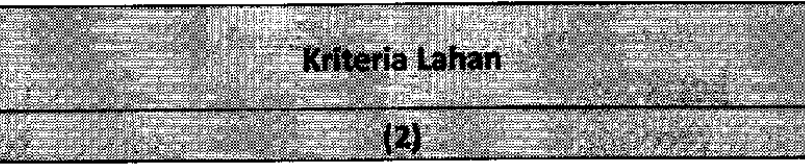 & 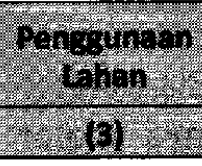 & 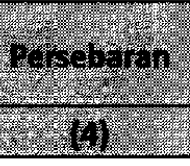 \\
\hline IV & $\begin{array}{l}\text { Kemampuan lahan sedang, mempunyai pembatas agak } \\
\text { basah, sehingga mengurangi pilihan penggunaan lahan, } \\
\text { memerlukan tindakan konservasi khusus, sesuai untuk } \\
\text { tanaman pangan tertentu dengan intensifikasi sedang }\end{array}$ & Tegalan & $\begin{array}{l}\text { Lembah } \\
\text { kaldera }\end{array}$ \\
\hline v & $\begin{array}{l}\text { Kemampuan lahan agak jelek, mengalami kerusakan } \\
\text { sedang, solum tanah tipis, relief bergelombang, cukup } \\
\text { tererosi, serta banyak berbatu. Lahan tidak sesuai } \\
\text { untuk tanaman semusim, lebih baik untuk vegetasi } \\
\text { permanen atau dihutankan }\end{array}$ & $\begin{array}{l}\text { Kebun } \\
\text { campuran }\end{array}$ & $\begin{array}{l}\text { Lereng } \\
\text { gunungapi } \\
\text { dan lembah } \\
\text { kaldera }\end{array}$ \\
\hline VI & $\begin{array}{l}\text { Kemampuan lahan jelek, solum tanah tipis, topografi } \\
\text { bergelombang sampai agak berbukit, lebih baik } \\
\text { diusahakan vegetasi permanen atau dihutankan }\end{array}$ & $\begin{array}{l}\text { Semak } \\
\text { belukar } \\
\text { dan lahan } \\
\text { kosongl }\end{array}$ & $\begin{array}{l}\text { Lereng } \\
\text { gunungapi } \\
\text { dan lembah } \\
\text { kaldera }\end{array}$ \\
\hline VII & $\begin{array}{l}\text { Kemampuan lahan jelek sekali, kerusakan berat, } \\
\text { sukar diperbaiki, relief kasar, erosi berat, lebih baik } \\
\text { dihutankan }\end{array}$ & $\begin{array}{l}\text { Lahan } \\
\text { kosong }\end{array}$ & $\begin{array}{l}\text { Lereng } \\
\text { gunungapi }\end{array}$ \\
\hline VIII & $\begin{array}{l}\text { Kemampuan lahan amat jelek sekali, kerusakan sangat } \\
\text { berat, relief kasar, erosi berat, sebaiknya dibiarkan } \\
\text { alami atau dihutankan. }\end{array}$ & $\begin{array}{l}\text { Lahan } \\
\text { kosong }\end{array}$ & $\begin{array}{l}\text { Lereng } \\
\text { gunungapi }\end{array}$ \\
\hline
\end{tabular}

Sumber: Diadaptasi dari FA0/CSR and staff, 1983; dalam Sutikno,dkk. 2007 dan hasil penelitian. 
Berdasarkan Tabel 3 dapat dikemukakan bahwa sebagian besar wilayah Kawasan Gunung Batur atau sekitar 8493.024 ha $(83.89 \%)$ memiliki kemampuan lahan yang bervariasi dari kelas V sampai kelas VIII. Kemampuan lahan seperti itu tidak bisa digunakan untuk tanaman semusim, sebaiknya diusahakan untuk tanaman berumur panjang, dihutankan atau dibiarkan dalam keadaan alami. Faktor pembatas peyebab rendahnya kemampuan lahan pada Wilayah Gunung Batur adalah, solum tanah dangkal, relief kasar dari berombak, bergelombang, hingga bergunung, di amping juga karena medan yang banyak berbatu dan singkapan batuan serta tererosi berat. Lahan dengan kemampuan kelas V - VIII ini secara luas tersebar pada lembah kaldera dan lereng kaldera.

Kemampuan yang lebih tinggi yaitu kelas IV, hanya dimiliki oleh sebagian kecil wilayah kaldera, yaitu 16309.76 ha atau $16.11 \%$ dari wilayah kaldera dan penyebarannya dapat dilihat di sebagian kecil wilayah di desa Buahan, Kedisan, dan Songan B. Lahan pada ketiga desa ini bisa ditanami tanaman semusim dengan pengelohan yang cukup intensif. Pengolahan pada lahan ditujukan untuk mempertebal solum tanah untuk mengurangi erosi, sehingga tanaman bisa tumbuh dengan lebih baik.

\section{b. Potensi Sumberdaya Air dan Pewila- yahannya}

Rata-rata jumlah curah hujan dalam kurun waktu 10 tahun terakhir (2000-2009) di Kawasan Gunung Batur adalah $2692.1 \mathrm{~mm} /$ tahun. Dengan demikian, maka Bentanglahan Wilayah Gunung Batur merupakan daerah dengan potensi curah hujan yang tergolong klasifikasi tinggi (P1). Tingginya klasifikasi curah hujan di Kawasan Gunung Batur tidak sepenuhnya dapat menjamin adanya kandungan air tanah yang tinggi (SP3 dengan debit $>5$ liter/detik) di daerah yang bersangkutan. Kandungan air tanah di Kawasan Gunung Batur secara umum sangat rendah (Sp1 dengan debit $<0.1$ liter/detik). Namun demikian, di beberapa daerah pinggiran danau terdapat kandungan air tanah yang terkategori sedang (Sp2 dengan debit 5-10 liter/ detik), terutama pada pinggiran bagian tenggara Danau Batur yaitu di desa Kedisan, Buahan, Suter, dan Trunyan dengan kandungan air tanah sebesar 5 liter/detik. Mata air (spring) dan rembesan (seepage) juga dijumpai di beberapa tempat di Kawasan Gunung Batur dengan debit air yang cukup besar (4 liter/detik). Mata air hanya dijumpai di Danau Batur dekat dengan obyek wisata Batur. Sedangkan rembesan dijumpai pada tekuk lereng atau pada dinding-dinding lereng Danau Batur.

Rendahnya kandungan air tanah di Kawasan Batur sangat terkait dengan wilayahnya yang berupa kaldera dan keadaan morfologi yang sebagian besar terjal mencapai kemiringan lereng $>40 \%$, serta rata-rata ketinggian daerah mencapai 750 meter dari permukaan laut. Kondisi tersebut menyebabkan air akan dengan cepat mengalir jauh masuk ke dalam tanah. Kawasan Gunung Batur memiliki danau yang merupakan danau terbesar dari 4 danau yang ada di Bali, yang sampai saat ini volume airnya masih dapat tetap terpelihara.

Sementara itu potensi airtanah Kawasan Gunung Batur berdasarkan parameter kedalaman muka air tanah, 
tergolong rendah (Sp3) yaitu dengan kedalaman muka air tanah mencapai $>15$ meter dan permiabilitas aquifer sebesar <0.5 mtr/hari. Dalam hal ini dapat dikemukakan bahwa potensi air tanah yang dimiliki Kawasan Gunung Batur tergolong kecil, dan itupun hanya dimiliki oleh desa-desa yang langsung berbatasan dengan danau.

Berkenaan dengan kualitas air tanah, digunakan empat titik lokasi sampel, yaitu di lahan pertanian (Songan), lahan hutan (Abangdinding), lahan permukiman (Buahan), dan lahan pariwisata (Toya Bungkah). Hasil analisisnya menunjukkan bahwa pada lahan pertanian, indikator sifat fisika, sifat kimia, dan sifat biologis yang berada di atas ambang batas air golongan B (air bersih) sudah tinggi. Pada lahan hutan, hanya sedikit indikator fisik yang melebihi ambang batas kualitas air golongan $B$, sedangkan indikator kimia sudah ada yang melebihi ambang batas. Untuk indikator biologi belum ditemukan bakteri Escheria Colli karena permukiman penduduk jauh dari hutan. Pada lahan permukiman di desa Buahan dan lahan pariwisata di Toya Bungkah, indikator fisik, kimia, dan biologi yang berada di atas ambang batas sudah cukup tinggi. Pencemaran air terjadi karena pengaruh dari limbah rumah tangga, hotel dan restoran yang langsung dibuang ke danau dan juga karena banyaknya penduduk yang mandi dan mencuci di danau. Dengan demikian dapat dikemukakan bahwa secara umum kualitas air tanah di Kawasan Gunung Batur sudah mengalami pencemaran. Berkenaan dengan itu untuk kebutuhan rumah tangga (air minum, masak) air tanahnya harus diolah teriebih dahulu dengan memasak sampai mendidih. c. Sumberdaya Mineral dan Pewilayahannya

Sumberdaya mineral di Kawasan Gunung Batur adalah berupa Bahan Galian $C$, khususnya pasir dan batu (sirtu). Material sirtu ini tersebar pada sebagian besar lereng dan lembah kaldera meliputi luas areal 7859.81 ha atau sekitar $77.64 \%$ Kawasan Gunung Batur. Penambangan bahan galian $\mathrm{C}$ pada Kawasan Gunung Batur teridentifikasi sudah diusahakan sejak lama, hal itu dapat dilihat dari cukup banyaknya lahan yang sudah digali, dan dibeberapa tempat bahkan menyisakan bekas lokasi penambangan. Bekas penambangan bahan galian $C$ nampak menyisakan lubang dan borok lahan di beberapa tempat yang amat merusak lingkungan.

Memperhatikan cakupan wilayahnya yang luas dan meliputi sebagian besar wilayah lereng bawah dan lembah kaldera, nilai guna bahan galian $C$ sangat berarti di Kawasan Gunung Batur karena kondisi kemampuan lahan di kawasan ini tergolong rendah, dan kesulitan air sehingga menyulitkan untuk diusahakan sebagai lahan pertanian. Namun, perlu diperhatikan bahwa dalam maksimalisasi pemanfaatan sumberdaya mineral yang ada selalu disertai dengan tetap menjaga kelestarian fungsi lingkungannya.

d. Sumberdaya Hutan dan Pewilayahannya

Tanaman hutan yang terdapat pada wilayah Kawasan Gunung Batur sebagian besar berupa hutan lindung yang tumbuh sepanjang dan sekitar igir kaldera. Fungsi hutan lindung sangat diperlukan untuk melestarikan air danau karena Danau Batur merupakan 
danau rebesan yang tidak punya aliran masuk (inlet) dan aliran ke luar (outlet). Tanaman hutan sebagian besar terdiri dari semak belukar perdu dan pakupakuan, hanya sebagian kecil hutan dengan pohon-pohon yang besar seperti pohon pinus (pinus mercusii), akasia (acacia decorens), Caliandra (caliandra callothyrsus), damar (agathis sp), rasamala (altingia exelsa), dan beringin (ficus benjamina). Tanaman hutan berupa semak belukar menempati areal $33.77 \%$ Wilayah Kawasan Gunung Batur yang dapat dijumpai di masing-masing desa, keculai di desa Songan A. Penyebaran hutan dengan pepohonan hanya menempati $5.60 \%$ wilayah Kawasan Gunung Batur, dan hanya dijumpai di empat desa, yaitu di desa Abangdinding, Sukawana, Buahan, dan desa Suter.

\subsection{Potensi Sosial Ekonomi Kawasan Gunung Batur Potensi Sumber- daya Manusia}

\section{Potensi Sumberdaya Manusia}

Kawasan Gunung Batur dihuni oleh 47492 orang dengan penyebaran penduduk pada desa-desa yang memiliki satuan morfologi dataran kaki gunung api $\left(\mathrm{V}_{4}\right)$. Besarnya jumlah penduduk merupakan cerminan dari adanya sumberdaya manusia di daerah tersebut. Namun, dilihat dari pendidikan yang pernah ditamatkan, 93.91\% penduduk usia 10 tahun ke atas di Kawasan Gunung Batur hanya berpendidikan dasar (SMP ke bawah), dan variasinya cukup konsisten di masing-masing desa. Kenyataan tersebut tentu menjadikan potensi suriberdaya manusia di Kawasan Gunung Batur secara kualitas masih rendah. Keberadaan sekolah di Kawasan Gunung Batur yang hanya punya satu SMA (di desa Songan A) dengan jarak dan medan yang berat, apalagi ditambah dengan perekonomian yang tidakmendukung, menyebabkan orang akan lebih memilih tidak melanjutkan sekolah.

Berdasarkan pekerjaan pokok yang berkembang di Kawasan Gunung Batur terdapat paling tidak 10 potensi sumberdaya manusia yang dapat teridentifikasi, yaitu dibidang pertanian lahan kering, peternakan, perikanan, perkebunan, perdagangan, industri, pengangkutan, perbangkan, jasa, dan pertambangan. Namun, potensi sumberdaya manusia yang dominan adalah di sektor pertanian (pertanian lahan kering, peternakan, perikanan, dan perkebunan), yaitu mencapai $81.22 \%$ dari total penduduk yang bekerja (usia 15 tahun ke atas) dan hamper konsisten antar desa.

\section{Potensi Pertanian}

Potensi pertanian yang terdapat pada Kawasan Gunung Batur sebagian besar berupa lahan untuk tanaman sayuran dataran tinggi, tanaman palawija, dan tanaman perkebunan. Kenekaragaman sumberdaya hayati berupa pertanian tidak begitu luas, salah satu penyebabnya adalah kemampuan lahan yang tergolong rendah. Sebagian besar lahan mempunyai kemampuan kelas V sampai kelas VI yaitu mencapai $83.89 \%$ dan kelas IV $16.11 \%$, sedang lahan yang memiliki kemampuan kelas I sampai III tidak dijumpai di Kawasan Gunung Batur.

Tanaman yang diusahakan petani pada saat penelitian lapangan dilakukan mencakup cukup banyak tanaman 
sayuran untuk dataran tinggi. Diantaranya adalah tanaman kubis (brassica oberca), sawi (brassica sp), kentang (solanum tuberosum), buncis (phasealus vulgaris), lombok (solanum annum), mentimun (cucumis sativus), seladri (apium graveoleus)), bawang merah, bawang putih, tomat (solamun licopersicum), wortel (daucus tabacum), bayam (amaranthus spitosum), dan jagung (zea mays). Tanaman semusim tersebut ditanam mengikuti pergiliran musim. Tanaman semusim ditanam di sela-sela tanaman keras seperti kopi (coffea sp), cengkeh (eugenis aromatica), nangka (arthrocarpus sp), mahoni (swietenia sp), dan jeruk.

\section{Potensi Perikanan}

Danau Batur luasnya mencapai $16.5 \mathrm{Km}^{2}$ dengan kedalaman rata-rata $50.8 \mathrm{~m}$, dan memiliki volume air seki$\operatorname{tar} 816,580,000 \mathrm{~m}^{3}$. Danau Batur merupakan potensi satu-satunya di bidang perikanan, karena Kawasan Batur tidak memiliki jenis perairan lainnya. Terdapat enam (6) buah desa yang berbatasan langsung dengan danau (mengelilingi danau) yaitu, Trunyan, Suter, Abangdinding, Buahan, Kedisan, dan Songan B. Dengan demikian dapat dikemukakan bahwa potensi perikanan yang dapat dikembangkan di Kawasan Gunung Batur adalah perikanan air tawar.

\section{Potensi Pariwisata}

Kawasan Batur di Kecamatan Kintamani memiliki keindahan panorama alam volkan dengan gunungapi aktif (Gunung Batur) dan danau volkanis (Danau Batur) yang dikelilingi oleh dinding kaldera yang terjal. Di samping itu, keunikan budaya terkait dengan kematian yang dimiliki masyarakat di desa Trunyan, Air panas di Toya Bungkah, serta aktivitas pertanian penduduk juga menjadi daya tarik Kawasan Gunung Batur sebagai daerah obyek wisata. Kawasan Gunung Batur juga menjadi lokasi 4 pura Kayangan Jagat yaitu masing-masing di desa $\mathrm{Ba}-$ tur Tengah, Songan B, Sukawana, dan Pinggan yang berpotensi dijadikan daya tarik pariwisata, serta Musium Volkanologi.

Di samping itu, dalam Rencana Tata Ruang Wilayah (RTRW) Provinsi Bali, wilayah Bali dibagi menjadi empat kawasan strategi sebagai kawasan pengembangan prioritas, yaitu Kawasan koordinasi kerjasama antar provinsi, Kawasan pusat pertumbuhan wilayah, Kawasan lingkungan hidup, dan Kawasan pengembangan daerah terpencil. Dari keempat kawasan strategis tersebut, tiga di antaranya bersentuhan dengan Kawasan Gunung Batur sebagai daerah tujuan wisata.

Berdasarkan paparan tersebut di atas dan penelusuran yang dilakukan di Kawasan Gunung Batur dapat dikemukakan sejumlah potensi yang dapat dikembangkan untuk pariwisata yaitu,

a. Wisata Alam

Kawasan Gunung Batur yang berupa kaldera yang terbentuk dari proses volkanikmemilikikeindahan alam, hutan, air panas (Toya Bungkah), danau, gunung hamparan lahar, semuanya memiliki potensi dikembangkan sebagai obyek wisata alam yang menarik wisatawan untuk mengunjungi Kawasan Gunung Batur.

b. Wisata Budaya

Budaya lokal masyarakat di Ka- 
wasan Gunung Batur dengan kebanuannya (danau), seperti penguburan mayat di desa Trunyan, tanaman pertanian dataran tinggi, dan empat Pura Kayangan Jagat yang tersebar di empat desa dengan lokasi yang sangat unik, semuanya dapat dikembangkan untuk pariwisata budaya.

c. Wisata Keilmuan

Fenomena volkanisme Kawasan Gunung Batur (kaldera yang memiliki danau dan gunungapi aktif), secara akademik menjadi sangat menarik untuk dipelajari, apalagi sudah ditunjang oleh adanya Musium Volkanologinya. Di samping itu, keberadaan desa-desa Bali Kuno di Kawasan Gunung Batur dipandang dapat dijadikan obyek untuk pengembangan pariwisata keilmuan.

\section{Simpulan}

\section{Karakteristik Bentanglahan Gunung Batur (Kawasan Gunung Batur)}

Secara geologis Kawasan Gunung Batur adalah sebuah kaldera yang terletak pada komplek gunungapi muda "zone Solo" yang disusun oleh tiga batuan yaitu Batuan Gunung Api Batur (Qhvb), Batuan Gunung Api Kelompok Buyan-Beratan dan Batur Purba (Qvbb), dan Batuan Gunung Api Kelompok Buyan-Beratan dan Batur Purba (Qpbb), dengan kemiringan lereng di atas $40 \%$ (terkategori terjal). Adapun morfologi wilayahnya dapat dikelompokkan menjadi lima (5), yaitu Kerucut Gunungapi $\left(V_{1}\right)$, Lereng Gunungapi $\left(V_{2}\right)$, Kaki Gunungapi $\left(V_{3}\right)$, Datā"an Antara Gunungapi $\left(V_{4}\right)$, dan Lembah cianau $\left(F_{1}\right)$, yang terdiri dari 2 jenis tanah yaitu, Regosol Kelabu (R) dan Andosol (A) yang kandungan "fraksi liat, debu, dan pasir". Konsentrasi "fraksi pasir" mencaiap $62.141 \%$ sedangkan "fraksi liat" hanya 3.92\%. Dengan demikian "tekstur tanah" di Kawasan Gunung Batur berkisar dari "lempung hingga lempung berpasir". Tipe iklim adalah berbertipe curah hujan " $C$ " atau wilayah dengan "tipe iklim agak basah" dengan bulan kering dalam setahun belangsung antara $3-4.5$ bulan dan termasuk tipe iklim Am, yaitu wilayah Iklim Hujan Tropis dengan curah hujan bulan terkering lebih kecil dari $60 \mathrm{~mm} /$ Tahun.

\section{Kondisi Kependudukan Bentanglahan Gunung Batur}

Penduduk Kawasan Gunung Batur yang berjumlah 47492 jiwa adalah penduduk yang berpendidikan rendah dengan dominan bekerja di sektor pertanian dengan pertumbuhan yang cukup tinggi (2.30\%). Penduduk Kawasan Gunung Batur bermukim di 14 desa dinas dengan sebaran penduduk yang lebih besar terdapat pada desa-desa yang memiliki susunan satuan morfologi dataran kaki gunungapi $\left(V_{4}\right)$ yang topografi wilayahnya relatif lebih datar. Sedangkan kepadatan penduduk sagrarisnya belum terkategori padat. Desa yang kepadatan penduduknya secara agraris terkategori padat ( $>100$ orang $/ \mathrm{Km}^{2}$ ) hanya terdapat di desa Kintamani.

\section{Potensi Sumberdaya Alam Bentanglahan Gunung Batur}

a. Potensi sumberdaya lahan di Kawasan Gunung Batur berdasarkan kemampuan lahannya berada pada kelas IV - VIII. Sebagian besar wilayah $(83.89 \%)$ kemampuan lahann- 
ya rendah (V - VIII), dan hanya sebagian kecil (16.11\%) yang dapat ditanami tanaman semusim.

b. Potensi air di Kawasan Gunung Batur dilihat dari curah hujan adalah tinggi (P1), namun kandungan air tanahnya umumnya sangat rendah (Sp1/1 liter/detik). Kedalaman muka air tanah juga rendah (Sp3) dengan permiabilitas aquifer sebesar $<0.5 \mathrm{mtr} /$ hari. Dilihat dari kualitas air tanahnya, secara umum kualitas air tanah di Kawasan Gunung Batur sudah tercemar terutama di daearah pertanian sehingga untuk keperluan minum dan masak perlu dipanaskan hingga mendidih untuk membunuh terutama bakteri Escheria Colli, sedangkan untuk MCK dan pertanian dapat digunakan langsung.

c. Potensi sumberdaya mineral yang dimiliki Kawasan Gunung Batur adalah berupa Bahan Galian C, khususnya pasir dan batu (sirtu). Material sirtu ini tersebar pada sebagian besar lereng dan lembah kaldera meliputi luas areal $77.64 \%$ dari total luas kawasan Gunung Ba$\operatorname{tur}\left(101.24 \mathrm{Km}^{2}\right)$.

d. Potensi hutan di Kawasan Gunung Batur Luas lahan mencakup luas $9.09 \mathrm{Km}^{2}$ ( 39.37\%) dan merupakan fungsi hutan lindung yang terdiri dari hutan dengan tanaman semak belukar, perdu dan paku-pakuan $\left(5.67 \mathrm{Km}^{2}\right)$ yang penyebarannya mencakup semua desa di kawasan Gunung Batur dan hutan dengan tanaman pepohonan $\left(3.42 \mathrm{Km}^{2}\right)$.

\section{Potensi Sosial Ekonomi Penduduk Bentanglahan Gunung Batur}

a. Potensi Sumberdaya Manusia
Kawasan Gunung Batur dihuni oleh 47492 orang yang dominan tersebar pada desa-desa yang memiliki satuan morfologi dataran kaki gunung api $\left(\mathrm{V}_{4}\right)$. Secara kualitas dilihat dari pendidikan yang ditamatkan 99,91\% penduduk hanya tamatan pendidikan dasar (SMP ke bawah) dan sebagian besar (81.22\%) bekerja di sektor pertanian lahan kering, perikanan, dan peternakan.

b. Potensi pertanian yang telah berkembang di Kawasan Gunung Batur sebagian besar berupa tegalan $\left(38.44 \mathrm{Km}^{2} / 37.97 \%\right)$ untuk tanaman sayuran dataran tinggi, tanaman palawija, sedangkan berupa perkebunan hanya $\left(10.98 \mathrm{Km}^{2} /\right.$ 10.98\%). Rendahnya kemampuan lahan menyebabkan terbatasnya kenekaragaman sumberdaya hayati sektor pertanian tidak begitu luas. Lahan yang dapat diolah untuk tanaman semusim luasnya hanya $16.11 \%$ yang tersebar pada lembah volkanik dekat dengan Danau Batur (Trunyan, Suter, Abangdinding, Buahan, Kedisan, dan Songan B). Lahan kelas IV seluruhanya sudah dimanfaatkan, bahkan telah merambah ke lahan kelas V dan VI.

c. Potensi perikanan di Kawasan Gunung Batur hanya terdapat pada Danau Batur yang luasnya $16.5 \mathrm{Km}^{2}$ dengan kedalaman rata-rata 50.8 $\mathrm{m}$, dan memiliki volume air seki$\operatorname{tar} 816,580,000 \mathrm{~m}^{3}$.Terdapat enam (6) buah desa yang berbatasan langsung dengan danau (mengelilingi danau) yaitu, Trunyan, Suter, Abangdinding, Buahan, Kedisan, dan Songan B. Dengan demikian dapat dikemukakan bahwa potensi perikanan yang dapat dikembangkan di Kawasan Gunung Batur adalah perikanan air tawar. 
d. Potensi pariwisata Kawasan Batur dapat dilihat dari sisi keindahan panorama alam volkan dengan gunungapi aktif (Gunung Batur) dan danau volkanis (Danau Batur) yang dikelilingi oleh dinding kaldera yang terjal. Di samping itu, keunikan budaya terkait dengan kematian yang dimiliki masyarakat di desa Trunyan, Air panas di Toya Bungkah, serta aktivitas pertanian penduduk juga menjadi daya tarik Kawasan Gunung Batur sebagai daerah obyek wisata. Kawasan Gunung Batur juga menjadi lokasi 4 pura Kayangan Jagat yaitu masing-masing di desa Batur Tengah, Songan B, Sukawana, dan Pinggan yang berpotensi dijadikan daya tarik pariwisata, serta Musium Vulkanologi. Pariwisata alam, pariwisata budaya, dan pariwisata keilmuan

\section{Rekomendasi}

Dari simpulan di atas secara kronologis telah teridentifikasi potensi Kawasan Gunung Batur sebagai suatu bentanglahan. Untuk selanjutnya perlu dilakukan pengkajian lebih lanjut melalui pengukuran-pengukuran terhadap potensi yang ada dengan menggunakan parameter-parameter yang dikembangkan sesuai dengan kebutuhan lapangan, terutama terkait dengan,

a. Nilai potensi (produk persatuan luas) yang dimiliki kawasan Gunung Batur dan kebutuhan penduduk akan potensi bersangkutan.

b. Kemampuan lingkungan Kawasan Gunung Batur sebagai suatu ekosistem untuk memasok sumberdaya alam dan untuk mengasimilasi zat pencemar serta ketegangan sosial.

c. Model pengelolaan sumberdaya alam untuk mendukung kehidupan sosial masyarakat adat, yaitu usaha untuk menunjukkan satu model pengelolaan sektoral pemanfaatan sumberdaya alam.

\section{Daftar Pustaka}

Bemmelen, R.W. Van. 1970. The Geology of indonesia. Hague; Martinus Nitholf.

Katili, J.A. 1983. Sumberdaya Alam untuk Pembangunan Nasiond. Jakartd; Ghalia indonesia.

Lakitan, Benyamin, 2002.Dosar-Dosar Kimatologi, Akarta; PT Raja Grafindo Persada.

Lillesand dan Kiefer, R.W. 1995. Remote Sensing and Image interppetation. New York; Prentice Hilll.nc.

Mitchell, B. B.Setiawan, Dwita Hadi Rahmi. 1997. Pengeloladan Sumberdaya dan lingkungan, Yogyakarta; Gadjä Mada University Press.

Notohadipromo. 1978. Gatro Fisik dalam pengeidican Iahan krits. Dalam Lahan Sumberdaya olam dan lingkungon Hidup Manusia. Yogyakarta; Departemen Tanah Fakultas Pertanian UGM.

Ramly, Nadjamudin, 2005. Membangun Lingkungan yang Berperadabon, Jakarta; PT. Raja Grafindo Persada.

Sunarto, 2003, Ekologi Bentanglahan, Materi Kuliah Ekologi Bentanglahan pada program 52 Inmu Lingkungan Program Pascasarjana UGM, Yogyakarta.

Suratman Worosuprojo, 1997. Ekologi Bentanglahon. Bahan Ajar Program Pascasarjana IImu Lingkungan Universitas Gadjah Mada, Yogyakarta.

Sutikno, Langgeng Wahyu Santosa, Widiyanto, Andri Kurniawan, Jaufik Hery Purwanto. 2007. Kergajan Merapi. Sumberdaya Alam \& Daya Dukungnya. Yogyakarta: Badan Penerbitan Fakultas Geograf (BPFG) Universitas Gadjah Mada.

Undang Undang No 22 Tahun 1999 Tentang Otonomi Daerah

Waryono, 1987. Pengantar Meteorologi don Kimmatologi. Surabaya; Bina IImu Offset, 